\title{
Teachers' Perspective on Strategy for Teaching English Vocabulary to Young Learners
}

\author{
Rahma Deni ${ }^{1}$ \\ UIN Syarif Hidayatullah Jakarta \\ rahmadeni42@gmail.com \\ Fahriany $^{2}$ \\ UIN Syarif Hidayatullah Jakarta \\ fahriany@uinjkt.ac.id
}

\begin{abstract}
Teaching and learning vocabulary is an integral part of foreign language learning since it is the basic sub-skill for someone who wants to learn a foreign language. Thus, it is essential to teach English vocabulary at an early age since students still in the scope of their golden age, and they could learn everything easily. In this case, the teachers' teaching strategy seems essential to be concerned. Moreover, this descriptive qualitative study as a case study is designed to explore the Qur'an Learning Center teachers' perspective on the strategy used to teach vocabulary to young learners. The data were gathered through a semi-structured interview with two English Teachers at the Qur'an Learning Center, one of the elementary schools in Jakarta Selatan. The result of this study revealed that teachers believe that teaching strategy is essential for teaching vocabulary to young learners. Thus, the teachers have various strategies that can be applied for teaching vocabulary to young learners, for example, using games, sing a song, and others. Also, the teachers used interesting media like video, a real thing, pictures, and others. Those strategies are effective in engaging students to learn new vocabulary in English. This study is expected to give reference and knowledge for the English teacher who teaches young learners so they could implement some suitable ways with their real class.
\end{abstract}

\author{
ARTICLE HISTORY \\ Received 8 May 2020 \\ Accepted 10 June 2020

\section{KEYWORDS} \\ Teachers' perspective; \\ teaching vocabulary; \\ strategy
}

\section{Introduction}

Teaching and learning English at a young age become more and more common in many countries around the world. It is due to the evaluation of economic globalization, governments in many parts of the world where English is spoken as an additional language have pushed for educational reform and introduce English since primary school level. Indonesia is one of the countries that has implemented teaching English to young learners (TEYL) since 24 years ago (Supriyanti, 2012). Moreover, Indonesian students believe that mastering English can increase independence. They 
will be able to compete with other people from where English becomes the first or second language. Therefore it is necessary to think strategy and system of teaching English to young learners in order to gain the optimal result. Although, in fact, English is only taught as a local content subject, extra-curricular, or additional subject in the Elementary level.

Moreover, teaching English at an early age seems essential since the students still in the scope of their golden age. As (Jones, 2015) asserted that teaching English in primary school is essential since it provides them English language skills in the golden age and the age that children can learn anything easily. Based on the study conducted by a team of scientists from McGill University in Canada, the optimal age to learn a second language is before the pre-puberty (Yow, \& Li, 2015) a. Additionally, students can learn and memorize things easily in this period. In order to acquire a language, vocabulary is one of the language components that students need to comprehend.

Additionally, it mentioned that vocabulary knowledge is an essential aspect of young learner language development. Elementary school is the first place for students to learn English formally. Also, the students learn the necessary thing in English, which is English vocabulary. Vocabulary is critical to be mastered first since it is an essential means of conducting communication (Wenyuan, 2017). Mastering vocabulary would be helpful for the students to assist them in comprehending the language being learned. Without vocabulary, nothing can be conveyed. Additionally, it is revealed that the quality of someone's skill in English depends much on their quality and the quantity of vocabulary mastered, the more vocabulary he mastered, the easier they develop four language skills (listening, speaking, reading and writing).

On the other hand, a teacher who has a background from the English education department only prepared to become a professional teacher for the secondary level. Hence, this could be a great challenge for the English teacher who is teaching English at the elementary school level (Nikolov, 2016). As we know, teaching students of the elementary school level is not the same as teaching adults, it needs different techniques and strategies. The teacher needs to manipulate some strategies to support the teaching and learning process. Also, teachers need to be creative to use appropriate media to make students engage with the topic. As (Kirkgoz, 2018) elementary school students are children who still like playing, so the teacher is expected to be imaginative and creative in developing their teaching strategy to make the English lesson more exciting.

Furthermore, teachers' perspective about teaching vocabulary to young learners seems essential to be observed since teachers' perspective may influence strategy and the way they deliver the material. In other words, teachers used various strategies depend on their perspective about the interesting and appropriate one for their students (Gaynor, 2018). Each strategy may result in a different response from the 
students. Thus, teachers' teaching strategy essential in teaching vocabulary to young learners. So, they could understand vocabulary as well as they are interested in the topic delivered through the exciting strategy.

A study about teachers' perspectives on strategy for teaching vocabulary had been conducted by some researchers. In this case, (Susanto, 2017) examined the perspective about teaching vocabulary to English Foreign Language Learner (EFL). The study indicated that vocabulary is an important part of foreign language learning. So, the teacher has various strategies for teaching vocabulary as well as their personal view about strategy for teaching vocabulary. Moreover, teachers applied some strategies for teaching vocabulary, such as teaching vocabulary using objects, drilling, spelling, drawing pictures, using expression and gesture, guessing from context, and using games. However, this study limited to the literature of using each strategy with some specific level, so it is difficult for imaging how the strategy can be applied. It can be quite clear if it has been illustrated how it can be applied appropriately.

Another critical study conducted by (Schmitt, 2015) identified the current perspective of teaching vocabulary for EFL learners. The study indicated that one key to facilitating a good way for learning is that maximizing learners' exposure to English vocabulary. It seems to indicate that this perspective guides the teacher to provide a strategy that can give students a chance to get exposure as much as possible. Additionally, (Schmitt, 2015) asserted that games are one of the alternative strategies that can be applied. It is due to games that engage students with teaching and learning activities.

Based on those previous studies, it seems to indicate that teaching strategy is very important, especially for teaching vocabulary, and it is related to the teacher's perspective about the right strategy to teach vocabulary for students. However, those studies applied to teachers who teach adult learners and adult EFL learners. It might have different results if this study conducted to English teachers who teach English to young learners. In terms of the existing gap in those studies, it is crucial to research teachers' perspectives on teaching vocabulary to young learners in order to facilitate young learners in language learning.

Therefore, this recent study aimed to identify the Quran Learning Center school teachers' perspective in teaching vocabulary to young learners. Moreover, this study formulated into three research questions: (a) What is the teachers' perspective on strategy for teaching vocabulary to young learners? (b) What is the problem found while implementing the teaching strategy for young learners? (c) What is the teachers' perspective in dealing with the problem found while teaching vocabulary? 


\section{Literature Review}

English language teaching for young children has the goal that they are expected to be able to understand English in a simple way that is based on listening, writing, reading, and speaking skills using selected topics related to their environmental needs. However, it will not work if students do not understand English vocabulary. Thus, teaching them vocabulary at an early age will help them accept learning goals from English subjects. Related to the above objectives, material for young students is generally about the center of their interests that they often face in their real lives. Topics include things in the classroom and things around the school. So, it is easier for them to do and absorb the words given about things in the classroom and things around the school.

Several ways suggested by (Korosidou \& Griya , 2016) these ways can be applied to teach young learners as it is mentioned below:

1) The teacher should be able to create enjoyable learning activities,

2) The teacher needs to create a comfortable situation so that the students no need to worry about making a mistake and they are willing to try something,

3) The teachers need to perform word or material with much action, picture, realia, and gesture,

4) The teachers should build an English speaking class or make the students willing to talk in English,

5) Teachers should know that young learners like to play a game and sing some songs

6) Teachers might try to tell a story with some properties and attractive voice

7) Teachers should know that it is ok if the students use their mother tongue sometimes,

8) Consistently recycle new language and add new things or to use words they will not know,

9) Teachers need to make a lesson plan with various activities.

In other words, teaching vocabulary to young children is not an easy thing to do. Teaching English to kindergarten students is not the same as teaching adults. It is due to they have different characteristics, motivations, and different learning goals. Therefore, the way of teaching must also be different from teaching adults. The teacher has a role in preparing ways, topics, and methods of delivering material for students. Therefore it is vital to know the teacher's perspective in teaching vocabulary to young students.

Teaching English to young learners has become essential in recent years. However, it is not always an easy task to teach the young learner. Many considerations should be taken on how to teach and what to teach. It is a fact that children are different from adults physically and mentally. 
Age has become a significant factor in formulating decisions on teaching students. The students who are considered as young learners enjoy studying language through loads of cheerful activities in a bright and colorful room. At the same time, adults are expected to use abstract notions since they can reason. As Harmer affirms that adults often encompass a clear understanding of why they are learning and what they wish to comprehend out of it.

Teaching young learners like kindergarten students is not the same as teaching adults because it possesses different characteristics as maintained by (Yusuf \& Rusdi, 2017) that children are not self-motivated and do not have a need to learn English immediately. They are not worried about a job or university degrees that need English comprehension. In other words, children and adults have a different motivation. Adults may learn a foreign language to get access to higher education or a better job while children may learn a foreign language because their parents send them to school. Children "s world is their daily games, events of interest to them, new knowledge that may come across, and a question that their inquisition minds may ask.

Furthermore, it seems essential for the English teacher to make some preparations before they teach English to young learners. In doing so, teachers need to find out some sources and information that relate to the teaching method or activities for young learners. One of the sources is the teacher itself. It means that teachers' real experience will describe in real how dealt with young learners. Thus, the teachers' perspective on this issue seems helpful for helping others in doing their task as a teacher.

\section{Methodology}

This qualitative study explored the teachers' perception of the strategy used for teaching vocabulary to young learners. This study was conducted in the Qur'an Learning Center school, which is one of the Elementary schools at Jakarta Selatan since the writer found that the Qur'an Learning Center's students mostly have good English vocabulary knowledge. It can be seen from the result of students' vocabulary test, which is conducted by the teachers as one of the evaluation tests. Moreover, two teachers who taught the first grade were chosen as participants in this study since they taught at the early level in which students still have limited English vocabulary knowledge.

Moreover, the primary data in this study is the teachers' perspective, so that the writer employed an in-depth interview with the participants. The interview was conducted twice since there are two participants in this study. The first session is on 30 December 2018, and it is conducted with Ms. Khoiriyah Achmad. Moreover, the second interview was conducted on 01 January 2019 with Ms. Nayla Jauhari. The writer conducted a semi-structured interview with both of the participants. The 
interview was conducted by having a face to face interview at the Qur'an Learning CentER's school. The interview guideline consists of three main topics and 18 questions. The first topic is aimed to gather teachers' perspective on the effective strategy for teaching vocabulary to young learners. The second, it is about problems found by the teachers when they applied some strategies for teaching vocabulary to young learners. The last is the teachers' perspective to solve the problem of the strategy used for teaching vocabulary.

The data was collected by recording the interview by using a mobile phone, and the researcher writes the interview transcription for then to be analyzed. The researcher addressed some processes in analyzing. First, the researcher wrote down the interview transcription with both participants. Second, the researcher attempted to organize the data. Third, the researcher coding and categorizing the data. Fourth, the researcher interprets the data. These steps are adopted from (Gibson, 2017).

Ms Khoiriya Achmad Khotib, and Ms Naila Jauhari were the participant in this study. Both of them have more than two-year experiences in teaching first-grade students at QUR'AN LEARNING CENTER, especially Ms Naila Jauhari she has been there for almost 5 years. It seems to indicate that both teacher have found some cases while teaching vocabulary and applied some strategies in their classes.

\section{Result and Discussion}

\section{Result}

In this part, the writer describes the result of this study gathered through the interview with the participants as well as answering the research questions. As it has been mentioned before there are three main results for this study:

1. Teachers' perspective on strategy for teaching vocabulary to young learners

Based on the interview with two participants, the data revealed that choosing an exciting strategy for teaching vocabulary depends on the level and the characteristic of the students. Moreover, the teachers view that an interesting strategy in teaching vocabulary for young learners is an activity that allows them to enjoy during the teaching and learning process. According to the teachers' experiences, they asserted that playing games and singing a song together are the most exciting way of learning vocabulary, especially among young learners.

\section{a. Playing games}

One of the interesting activities that young learners interest in is game. Teachers also use games in teaching vocabulary and give them some reward for the one or group who win the games. For example, in teaching about animals, the teacher divides the class into two groups, and she describes the characteristic of the animal with gestures, also facial 
expressions. Finally, each group may answer the name of the animals. The group that guests many animals will be the winner and get the reward.

Then the teacher said that matching games are also applied in the classroom. The teacher gives two-card group A get a picture, and group B gets the name related to the picture, then each student should find their couple. As Ms. Nayla said that "Pernah main pake kartu snap mereka cari kartu yang berpasangan yang gambar dan tulisannya sesuai". (Interview with Ms Nayla on Tuesday, 1 January 2019).

b. Sing a song

The other strategy is by using a song. The students will enjoy the lesson when the teacher plays or asks them to sing along together. The teacher teaches the students by pointing the part of the body based on the song. As the teacher said that "untunk penggunaan lagu contohnya ketika mengajarkan part of the body anak-anak akan lebih tertarik ketika menggunakan nyayian dan gerakan seperti contohnya ketika memakai lagu one little finger". (Interview with Ms Nayla on Tuesday, 01 January 2019).

Additionally, teachers also mentioned that material and media play essential roles in teaching vocabulary to young learners. Before entering the class, the material is an essential thing that should be prepared by the teachers. The aim of using material is to develop students' abilities and knowledge. The material should follow and appropriate with the lesson plan and syllabus. Several materials should be taught to first-grade students such as colors, clothes, animals, name of thing, and etc.

Moreover, after knowing the material, the teacher should prepare the media related to the material in order to support the teaching-learning process. Therefore, students can easily understand the topic. Several media can be used to make the young learner engage and happy during the teaching and learning process. Based on the interview, both participants have the same opinion about the media. Here are several media that commonly used by the teachers of firstgrade students in the Qur'an Learning Center school, for example, picture, realia or real-thing, video, and sometimes also supported by using textbooks. Based on the interview both participants explain about the media as mention bellows;

\section{a. Using Real Thing}

There are so many media that can be used to teach vocabulary, and one of that media is realia or the real thing. Bring real things to students is helpful for explaining the meaning of the new vocabulary rather than only mention the meaning of the vocabulary in a word, for example, the teacher 
can present some words such as cellular phone, pencil, bag, shoes, and many others thing in the real inside of a classroom.

As interview conducted with the teachers, the teachers also mentioned that they use realia to explain new word for the students and students really enjoy it Ms Khoiriya said that "saya sering memakai realia contohnya kita suka pake origami, atau clothes pictorial, bahkan kami suka bawa langsung contoh real dari clothes." (Interview with Ms Khoiriya on Monday, 31 December 2018).

b. Using and drawing pictures

Pictures are also common media used by many teachers, especially for teaching vocabulary. In the Qur'an Learning Center, teachers not only showing some pictures about new vocabulary but also ask the students to draw some pictures by using colorful pencils it seems more interesting for first-grade students since many of them like drawing. While based on the interview, the teacher said that "media yang digunakan seperti gambar. Kami memberikan anak crayon warna warni dan meminta mereka untuk menggambar kenapa? Karena kebanyakan anak-anak sangat suka menggambar dan mewarnai." (Interview with Ms. Khoiriya on Monday, 31 December 2018).

And Ms Nayla also explain that using picture is also important to provide students who has visual learning style as she said that "penggunaan gambar itu perlu banget untuk mengakomodasi anak-anak yangmemiliki gaya belajar visual" (Interview with Ms. Nayla on Sunday, 30 December 2018).

c. Using video

As the result of the interview, both of the teachers mentioned that they also used video as a media to teach vocabulary to students. Ms Nayla mentioned in the interview that that "setiap kelas itu ada TV nya sebagai pengganti LCD nah kita sering menggunakan TV tersebut untuk memutar kan video dan anak sangat tertari sekali dengan penggunaan video ini dan penggunaan video juga penting untuk memfasilitasi anak- anak yang memiliki gaya belajar audio dan visual atau adiovisual". (Interview with Ms. Nayla on Sunday, 30 December 2018).

d. Using Textbook

Teachers in the Qur'an Learning Center mostly used coursebooks to give some exercise and activity for students since they used two curricula, such as Cambridge and National Curriculum 2013. Therefore, teachers used the course book as an evaluation media. As Ms. Khoiriya said in an interview that "jadi dibukunya lebih sering latihannya karena memang sudah ada activity yang harus dikerjakan setelah memahami materi." (Interview with Ms. Khoiriya on Monday, 31 December 2018). 
2. The problem found while implementing the teaching strategy to young learners

Based on the interview done by the researcher, the researcher found that there were some problems faced by the teachers in the Qur'an Learning Center School when the teachers attempt to teach English vocabulary to young learners. The problem classified into two main points.

The first problem seems to come from the students. As a result of the interview, it is not an easy thing to teach first-grade students of elementary school. Most of the students know nothing about the English language. Both of the participants consider that students not focus on the class and still difficult to be controlled. Meanwhile, all of the students who passively involve and know nothing about English: the teacher also mentions that some students are actively involved during the classroom activity.

The second problem comes from the English teacher; teachers realize that they do not have enough time to prepare some media and strategy for teaching vocabulary to young learners. Therefore, they feel confused and do not know what to teach sometimes in class. As a result, they only use course books in the class.

3. Teachers' perspective in dealing with the problem found while teaching vocabulary

There are some solutions found by teachers to fix the problems, such as giving the students reward to indicate that students have done their best in a classroom activity. As Ms. Khoiriya said in an interview that "jangan salah ya anak kelas satu ini dikasih reward bintang dipapan tulis saja itu udah seneng banget sampe kejar-kejaran sama teman-temannya untuk mendapatkan bintang lebih banyak. (Interview with Ms. Khoiriya on Monday, 31 December 2018). Teachers also give learning motivation for the students, but they do not force students to learn since they still in the first grade of elementary school. As Ms. Khoiriya also said in an interview that "motivasi buat anak pasti ada tapi kita belum pada tingkat memaksa belajar karena anak masih dalam tingkatan bermain yang belum bisa dipaksa. Takut kalau dipaksa yang ada anaknya nanti stres. (Interview with Ms. Khoiriya on Monday, 31 December 2018).

Both of the participants or the teachers in this study also suggest creating an innovative strategy for teaching vocabulary to young learners; for example, a strategy used by the teachers is matching games. In this activity, the student will get the picture of an animal and the name of the animal. Then the teacher will play the song when the music stops. Each student should find a hand on the picture and find their friend. When the teacher plays music, students should sing together and hide their cards 
again. Repeat it several times until all of the students find their friends. Additionally, both of participants assume that teachers need to be aware of students' need since the teacher not only someone who transfer some knowledge, but also someone who is able to help students to fulfil their need in term of exploring students' skill.

\section{Discussion}

Based on the result above, it can be interpreted that vocabulary is the basic aspect for someone to learn a foreign language. Considering the importance of vocabulary, it seems essential to teach vocabulary to the early level of education, in this case, the elementary school level. It is supported the statement of (Susanto, 2017) who asserted that vocabulary is an important part of learning a foreign language so that it is better for students to learn it at an early age or early level of education. However, it is not an easy job to teach English vocabulary to young learners. Qur'an Learning Center is one of the private Elementary schools in Jakarta which applied English as a subject to be taught since the first grade. In addition, teachers' teaching strategy seems interesting to be observed (Kalantari \& Hashemian, 2016). Therefore, this study centers on identifying teachers' perspectives on teaching vocabulary strategy to young learners.

In light of the study conducted by (Schmitt, 2015), it has a similarity with this study in terms of the design and the object of the study in which the previous study also discussed perspective on teaching English vocabulary. Moreover, the result of this recent study, indicated that teachers' selected the teaching strategy by considering students' characteristics. In this study, the students still in the first grade of Elementary school mean that they still have difficulties in learning something in a monotonous way or the difficulty of focusing on the material. Therefore, teachers in the Qur'an Learning Center applied an enjoyable and fun strategy to learn vocabulary, for example, games, and sing a song. This result automatically supports the previous study by (Bakhsh, 2016) who found that games can be an interesting tool in teaching vocabulary to young learners.

Another result is that teachers of the Qur'an Learning Center view sing a song as one of activity that enjoyable and engages students to learn vocabulary in the class. For example, when students learn basic vocabulary about parts of the body. It could be easier to remember the vocabulary through song rather than memorize it intentionally. It is in line with the previous research conducted by (Tse, 2015) which revealed that learning vocabulary through song bring students a new teaching environment that more enjoyable and fun. Thus, students can learn something easily in a fun way.

Moreover, the results also indicated that teachers commonly faced some problems in teaching vocabulary to young learners; for instance, students are difficult to be controlled, and teachers have to lack preparation before teaching the vocabulary 
to students. This result seems similar to (Bakhsh, 2016) who research using a game to teach vocabulary to Saudis children. Moreover, Bakhsh found that Saudis could learn the foreign language easily; however, they also could easily bored with the conventional method used by the teachers. It is also supported by (Pinnter, 2015) who asserted that young learners commonly not focus on the material.

Furthermore, both participants in this study asserted that teachers should be creative to create an alternative teaching strategy for teaching vocabulary to young learners one of the alternative strategies can be matching games or any other activities. It was also mentioned by (De Melendex, \& Beck, 2018) that teachers need to provide the interesting strategy media, and activity so that young learners will learn something easily since they are happy during the learning process.

\section{Conclusion}

Based on the data interpretation and the findings of the study, the researcher concludes that there three main points in this research. First, there are some teaching strategies implemented by Ms Khoiriya A Chotib,and Ms Naila Jauhari in the first grade students of the Qur'an Learning Center school, such as using some games and songs. Moreover, the teacher also used some media such as pictures, video, realia, textbook to support the students in learning new vocabulary which is related to these topics such as colors, clothes, animals, name of the thing, and others

The second, there are some problems faced by the teacher and students in teaching and learning activities. The problem of implementing teaching vocabulary strategy is derived from the students and the teachers. Some students have less attention and not focus during the teaching and learning activity. What is more, the first-grade students have fundamental knowledge about English, even, some of the students know nothing about English. The second problem comes from the teacher, and the teacher has less time to prepare the media, sources, and strategy for teaching English vocabulary.

Third, there are some solutions provided by the teacher to overcome some problems in teaching English vocabulary. First, the teacher should understand the students' needs and provide some interesting strategies to teach the students. Therefore, students will be motivated and happy in the teaching and learning process. The second, reward students to appreciate that they did a great job in the class, and this reward also able to motivate students to become active in the class

Moreover, the results of this study are expected to gain the teachers' understanding of teaching vocabulary strategy for young learners. Furthermore, it can apply for other researchers in further study to conduct a similar perspective about teaching vocabulary strategy.

The study is limited in terms of the equipment. It is due to the researcher only use an interview as a means for collecting the data. For further research, it would be 
Rahma Deni, Fahriany | 59

better if the data gathered through some additional instruments. In other words, further research is expected in the same area with various equipment so that it could enrich the information about teaching vocabulary strategy for young learners. 


\section{References}

Bakhsh, S. A. (2016). Using Games as a Tool in Teaching Vocabulary to Young $\begin{array}{lllll}\text { Learners. } & \text { English }\end{array}$ https://doi.org/10.5539/elt.v9n7p120

De Melendez, W. R., \& Beck, V. (2018). Teaching young children in multicultural classrooms: Issues, concepts, and strategies. Cengage Learning.

Gaynor, B. (2018). 5 Teaching English to young learners in Japan: Teacher competence and classroom context. New Perspectives on the Development of Communicative and Related Competence in Foreign Language Education, 28, 71.

Gibson, Nancy. (2017). A Step-By-Step Guide To Qualitative Data Analysis. Researchgatepublication.

Gungor, M. N. (2016). Turkish pre-service teachers' reflective practices in teaching English to young learners. Australian Journal of Teacher Education, 41(2), 9.

Jones, J. (2017). Teaching English to young learners. Critical issues in language teaching with 3-12 years olds . Edited by Jean Bland . British Journal of Educational Studies, 65(1), 130-132. https://doi.org/10.1080/00071005.2017.1282092

Kalantari, F., \& Hashemian, M. (2016). A Story-Telling Approach to Teaching English to Young EFL Iranian Learners. English Language Teaching, 9(1), 221-234.

Kırkgöz, Y. (2018). Teaching English To Young Learners: An Observation And Evaluation Of Effective Teaching Strategies. In 1st International Conference On Language, Education And Culture (Iclec) (p. 50).

Korosidou, E., \& Griva, E. (2016). " It's the same world through different eyes": a content and language integrated learning project for young EFL learners. Colombian Applied Linguistics Journal, 18(1), 116-132.

Nikolov, M. (Ed.). (2016). Assessing young learners of English: Global and local perspectives. Berlin: Springer.

Pinter, A. (2015). International perspectives on teaching English to young learners. 
Schmitt, N. (2015). International Handbook of English Language Teaching. International Handbook of English Language Teaching, (September). https://doi.org/10.1007/978-0-387-46301-8.

Siyanova-Chanturia, A., \& Webb (2016). Teaching vocabulary in the EFL context. In English Language Teaching Today (pp. 227-239). Springer, Cham.

Susanto, A. (2017). the Teaching of Vocabulary: a Perspective. Jurnal KATA, 1(2), 182. https://doi.org/10.22216/jk.v1i2.2136

Tse, A. Y. H. (2015). Malaysian teachers' perspectives on using songs in English language teaching. International Journal of Social Science and Humanity, 5(1), 87.

Wenyuan, G. (2017). Using smart phone to facilitate vocabulary mobile learning and teaching in Chinese college .International Journal of Arts and Commerce, 6(4), 41-36.

Yow, W. Q., \& Li, X. (2015). Balanced bilingualism and early age of second language acquisition as the underlying mechanisms of a bilingual executive control advantage: why variations in bilingual experiences matter. Frontiers in psychology, 6, 164.

Yusuf, Q., Asyik, A. G., Yusuf, Y. Q., \& Rusdi, L. (2017). " Listen, Do, Repeat, Understand and Remember": Teaching English to Very Young Children in Aceh. Iranian Journal of Language Teaching Research, 5(2), 113-132. 